NUREG/CR-2878PNL-4373

\title{
Detection of Small-Sized Near-Surface Under-Clad Cracks For Reactor Pressure Vessels
}

Prepared by T.T. Taylor, S.L. Crawford, S.R. Doctor, G.J. Posakony

Pacific Northwest Laboratory

Operated by

Battelle Memorial Institute

Prepared for

U.S. Nuclear Regulatory

Commission 
This report was prepared as an account of work sponsored by an agency of the United States Government. Neither the United States Government nor any agency thereof, or any of their employees, makes any warranty, expressed or implied, or assumes any legal liability of responsibility for any third party's use, or the results of such use, of any information, apparatus, product or process disclosed in this report, or represents that its use by such third party would not infringe privately owned rights.

\section{Availability of Reference Materials Cited in NRC Publications}

Most documents cited in NRC publications will be available from one of the following sources:

1. The NRC Public Document Room, 1717 H Street, N.W. Washington, DC 20555

2. The NRC/GPO Sales Program, U.S. Nuclear Regulatory Commission, Washington, DC 20555

3. The National Technical Information Service, Springfield, VA 22161

Although the listing that follows represents the majority of documents cited in NRC publications, it is not intended to be exhaustive.

Referenced documents available for inspection and copying for a fee from the NRC Public Document Room include NRC correspondence and ir.ternal NRC memoranda; NRC Office of Inspection and Enforcement bulletins, circulars, information notices, inspection and investigation notices; Licensee Event Reports; vendor reports and correspondence; Commission papers; and applicant and licensee documents and correspondence.

The following documents in the NUREG series are available for purchase from the NRC/GPO Sales Program: formal NRC staff and contractor reports, NRC-sponsored conference proceedings, and NRC booklets and brochures. Also available are Regulatory Guides, NRC regulations in the Code of Federal Regulations, and Nuclear Regulatory Commission /ssuances.

Documents available from the National Technical Information Service include NUREG series reports and technical reports prepared by other federal agencies and reports prepared by the Atomic Energy Commission, forerunner agency to the Nuclear Regulatory Commission.

Documents available from public and special technical libraries include all open literature items, such as books, journal and periodical articles, and transactions. Federal Register notices, federal and state legislation, and congressional reports can usually be obtained from these libraries.

Documents such as theses, dissertations, foreign reports and translations, and non-NRC conference proceedings are available for purchase from the organization sponsoring the publication cited.

Single copies of NRC draft reports are available free upon written request to the Division of Technical Information and Document Control, U.S. Nuclear Regulatory Commission, Washington, DC 20555.

Copies of industry codes and standards used in a substantive manner in the NAC regulatory process are maintained at the NRC Library, 7920 Norfolk Avenue, Bethesda, Maryland, and are available there for reference use by the public. Codes and standards are usually copyrighted and may be purchased from the originating organization or, if they are American National Standards, from the American National Standards Institute, 1430 Broadway, New York, NY 10018. 
NUREG/CR-2878

PNL-4373

R5

\section{Detection of Small-Sized Near-Surface Under-Clad Cracks For Reactor Pressure Vessels}

Manuscript Completed: January 1983

Date Published: February 1983

\section{Prepared by}

T.T. Taylor, S.L. Crawford, S.R. Doctor, G.J. Posakony

Pacific Northwest Laboratory

Richland, WA 99352

\section{Prepared for}

Division of Engineering Technology

Office of Nuclear Regulatory Research

U.S. Nuclear Regulatory Commission

Washington, D.C. 20555

NRC FIN B2289 


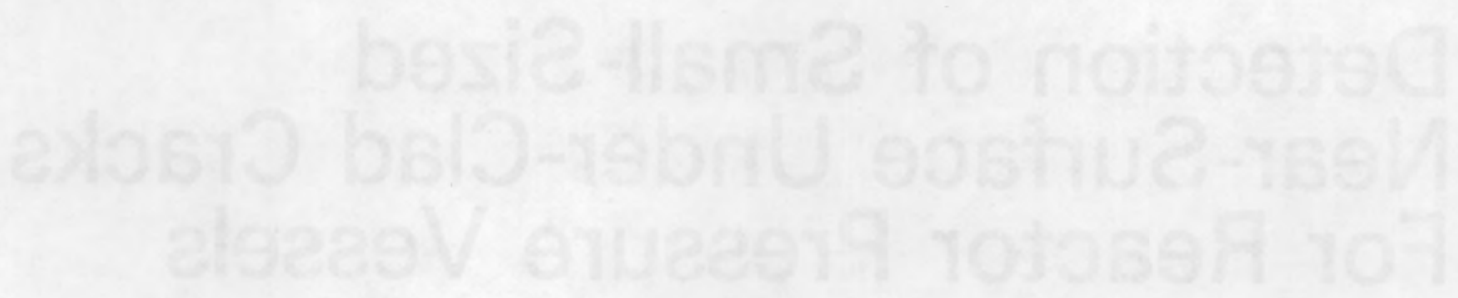

3ach

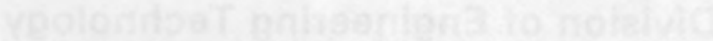

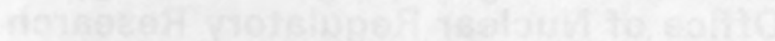

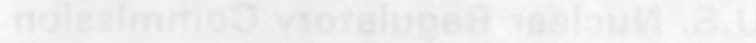




\section{ABSTRACT}

The analysis of pressurized thermal shock (PTS) shows it is necessary for nondestructive evaluation to demonstrate high probability of detecting cracks 0.250 inches deep and deeper at the clad/base metal interface.

Ultrasonic techniques developed and used in Europe are evaluated in this paper for their applicability to U.S. reactor pressure vessels for detecting cracks of interest for PTS.

Flaw detectability experiments were carried out by testing the inspection technique's ability to detect artificial flaws under several types of clad, including some Manual Metal Arc (MMA) clad. Both ground and unground clad surfaces were evaluated. Crack sizing tests of the inspection technique were made using a crack tip diffraction technique.

The data reported here indicate that for sufficiently smooth clad surfaces, the dual $70^{\circ}$ compressional wave technique is extremely effective for detecting under-clad cracks. In addition, results show that dramatic signal-to-noise improvements can be made by grinding the clad surface. Specifically, an improvement of 10 to $12 \mathrm{~dB}$ in signal-to-noise ratio was achieved by smoothing the clad surface roughness from $12.6 \times 10^{-3}$ inches RMS to $5.6 \times 10^{-3}$ inches RMS. The improvement in surface finish allowed sufficient ultrasound to penetrate the clad surface to improve crack detection confidence from low to very high. 



\section{EXECUTIVE SUMMARY}

It has been postulated that small ( 0.25 inch deep) cracks beneath the clad of pressure vessel belt line welds could result in vessel failure during a reactor overcooling transient. Nondestructive evaluation must demonstrate a high probability of detecting these small cracks. The cracks of interest lie parallel or perpendicular to the clad lay and within the first one inch of the vessel surface.

European techniques (DeRaad, Engl and Bergh, 1981; Launay et al., 1981) using $70^{\circ}$ compressional waves have been shown to be effective in detecting under-clad cracks $3 \mathrm{~mm}$ deep or shallower under ideal conditions (smooth clad and cracks predominantly perpendicular to the clad lay). Most circumferential welds in U.S. pressure vessels have been clad using the manual metal arc (MMA) process. This welding process creates rough surfaces that contribute to ultrasonic inspection noise and inhibit inspection effectiveness. This paper reports progress in a program in which the Pacific Northwest Laboratory is evaluating European and other inspection techniques that may be useful for inspecting U.S. pressure vessels.

Flaw detectability experiments were carried out by testing the inspection technique's ability to detect artificial flaws under several types of clad, including MMA clad. Both ground and unground clad surfaces were evaluated. Crack sizing tests of the inspection technique were made using a crack tip diffraction technique.

The data reported here indicate that for sufficiently smooth clad surfaces, the dual $70^{\circ}$ compressional wave technique is extremely effective for detecting under-clad cracks. In addition, results show that dramatic signal-to-noise improvements can be made by grinding the clad surface. Specifically, an improvement of 10 to 12 dB in signal-to-noise ratio was achieved by smoothing the clad surface roughness from $12.6 \times 10^{-3}$ inches RMS to $5.6 \times 10^{-3}$ inches RMS. The improvement in surface finish allowed sufficient ultrasound to penetrate the clad surface to improve crack detection confidence from low to very high.

The results of flaw detectability experiments reported in this paper show that few U.S. reactor vessels have been effectively examined for Pressurized Thermal Shock (PTS) type flaws. The conclusions (on page 17) suggest changes to Codes and/or regulatory guides that would improve detection of PTS-type flaws. 



\section{CONTENTS}

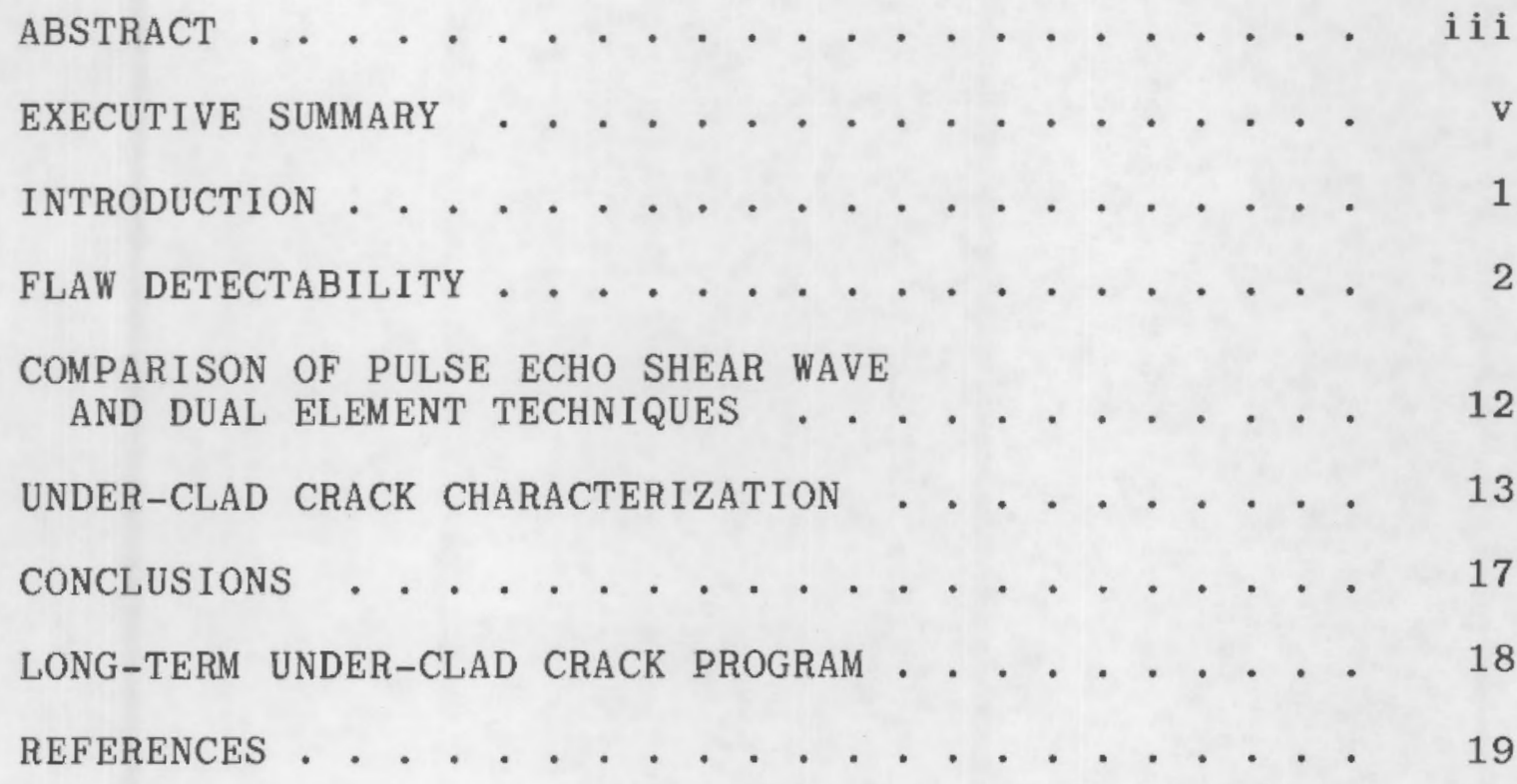





\section{FIGURES}

1. Probe for Under-Clad Crack Detection . . . . . 2

2. Flaw Response from Pressurizer Dropout . . . . 4

3. Relative Amplitude Response of Ground Strip Clad Sample with Under-clad Notches . . . . . 5

4. Relative Amplitude Response of Unground Strip Clad Sample with Under-clad Notches . . . . . 5

5. Relative Amplitude Response of Ground SingleWire Subarc Clad Sample with Under-clad Notches . 6

6. Relative Amplitude Response of Unground SingleWire Clad Sample with Under-clad Notches . . . . 6

7. Test Blocks for Background Noise....... 8

8. Background Noise Measurements . . . . . . 9

9. Surface Condition Before Grinding . . . . . 10

10. Surface Condition After Grinding . . . . . . 10

11. Scatter of Ultrasound through an Unground Clad Surface.............. . 11

12. Scatter of Ultrasound through a Hand Ground Clad Surface... . . . . . . . . . . 11

13. Scatter of Ultrasound through an Ideal (Smooth) Surface.............. . 12

14. Crack Tip Diffraction Technique for Sizing Under-clad Cracks . . . . . . . . . . . . 14

15. Experimental Sizing Data for $60^{\circ}$ Longitudinal Wave ................ . 15

16. Experimental Sizing Data for $45^{\circ}$ Longitudinal Wave................. 16

17. Sound Path through $\mathrm{Clad}$ Surface for Shear Waves . 16

18. Correlation of Proposed Sound Path to Experimental Data 



\section{TABLES}

1. Flaw Amplitude Response from Nine Under-Clad Thermal Fatigue Cracks . . . . . . . . . 3

2. Estimate of Relative Detectability of UnderClad Cracks Greater than $6 \mathrm{~mm}$ in an Optimized System . . . . . . . . . . . 13

3. Crack Sizing Data for Matrix I Flaws . . . . . . 14 



\section{DETECTION OF SMALL-SIZED NEAR-SURFACE \\ UNDER-CLAD CRACKS IN U.S. PRESSURE VESSELS}

\section{INTRODUCTION}

The belt 1 ine welds in the pressure vessels of several U.S. reactors have suffered serious radiation damage. This damage resulted from high copper content in the welds. It has been postulated (Gamble and Strosnider) that under-clad cracks as small as .250 inches in depth could result in vessel failure during an overcooling transient. A combination of conditions would be required for this type of failure to occur. These include: crack existance, high radiation damage, and high pressure (approaching operating pressure) at a low temperature. This generic safety issue is identified as Pressurized Thermal Shock (PTS).

The ability of nondestructive evaluation (NDE) to detect and characterize flaws provides an opportunity to assess the integrity of the inner surface of the vessel. Currently, a specialized technique developed in Germany and France is generally accepted as providing optimum detection resuls (DeRaad, Engl and Bergh; Launay et al.; Becker; Gruber). At the direction of the U.S. Nuclear Regulatory Commission (NRC), the Pacific Northwest Laboratory (PNL) is evaluating the effectiveness of this technique. The objective of this study is to provide NRC with information on how well the technique detects flaws in pressure vessels fabricated in the U.S.

The technique developed in Europe utilizes high-angle (generally greater than $50^{\circ}$ ) compressional waves. This technique was developed to detect under-clad cracks in light water reactor vessels. Inspection is performed with the search unit in contact with the clad surface (i.e., near surface flaw detection). It has been shown to be effective in detecting under-clad cracks 3 millimeters deep under ideal conditions (smooth clad and cracks predominantly perpendicular to the clad lay). Figure 1a shows the directivity pattern in steel of a $70^{\circ}$ zone focused compressional wave emitted from a dual element transducer. The directivity pattern in Figure 1a shows that the peak energy of a $70^{\circ}$ zone focused transducer 1 ies between 0.25 in. and 0.5 in. below the surface of the metal, which makes the high-angle compressional waves ideal for detecting defects near the clad/base metal interface. The compressional waves have better penetrating power through clad than shear waves, providing a better signal-to-noise ratio. Commercially available transducers specially designed for under-clad-crack detection incorporate a transmit/receive design that allows the highangle zone focusing (see Figure 1b). 


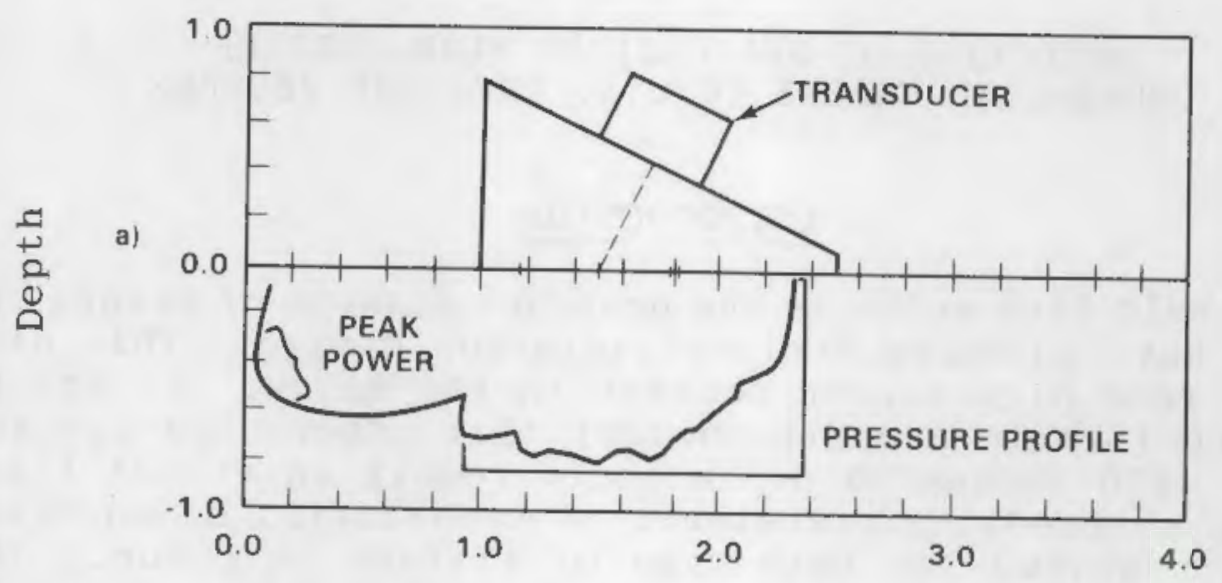

b)

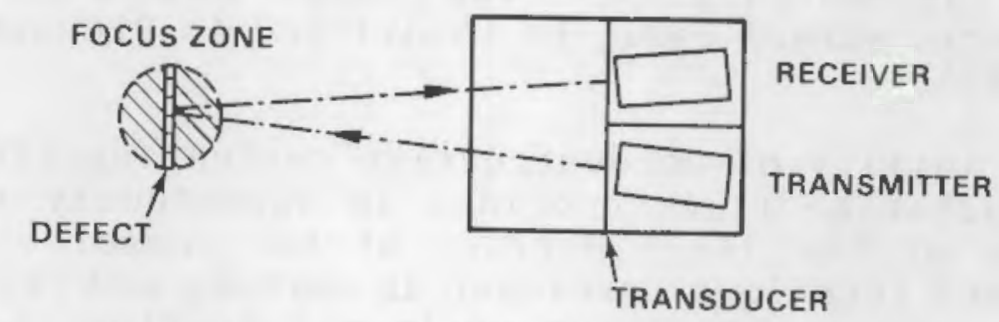

FIGURE 1. Probe for Under-clad Crack Detection: a) Directivity Pattern for $70^{\circ}$ Compressional Wave; b) Send/Receive Design for Commercial Probes.

The PNL evaluation of this technique included an assessment of flaw detectability and initial crack characterization experiments. This evaluation is part of a long-term NRC program designed to identify ultrasonic inspection technology that can reliably detect and characterize cracks beneath the clad of a reactor pressure vessel. This report deals with study results to date. The following report section discusses flaw detectability experiments in which European technique were used to detect artificial flaws under several types of clad. The subsequent section describes crack characterization experiments. Conclusions are followed by a discussion of plans for the long-term program.

\section{FLAW DETECTABILITY}

Flaw detectability experiments have been carried out on strip clad, single-wire subarc clad, and manual clad. Both ground and unground surfaces were evaluated. The test blocks used for this evaluation included: a $29.5 \mathrm{in}$. dia. clad dropout, two 23.6 in. square blocks with strip and single-wire clad with 
one side ground and the other as deposited,(a) and two small samples with ground and unground, manually clad surfaces. The pressurizer dropout contained through-clad notches as well as thermal fatigue cracks under the clad. The two EPRI blocks contained notches under the clad (under-clad notches). The two manually clad samples contained two reference reflectors each and were used to evaluate general noise level.

The measurements reported here were taken using a $2-\mathrm{MHz}$ dual-beam longitudinal (SEL) $70^{\circ}$ transducer with .39 x .59 in. elements and focal zone of .67 in. This unit was considered optimal for the clad conditions and thicknesses (.25 to .35 in. tested. All measurements were performed manually.

Measurements of flaw amplitude response from each of the under-cIad thermal fatigue cracks (labeled A through I) in the pressurizer dropout sample were compared with the amplitude response from a $1 / 8$ in. dia., flat-bottom reference reflector (Table 1). The flaw amplitude response was measured from two directions ( $180^{\circ}$ apart) as would be done during actual field tests. The amplitude responses were higher than responses from the reference reflector; therefore, these cracks should be easily detectable with this technique even under field conditions.

TABLE 1. Flaw Amplitude Response from Nine Under-Clad Thermal Fatigue Cracks

\begin{tabular}{|c|c|c|c|c|c|}
\hline & $\begin{array}{l}\text { Flaw } \\
\text { Depth } \\
\text { Through }\end{array}$ & \multicolumn{4}{|c|}{ Flaw Response (b) } \\
\hline Flaw & $\begin{array}{l}\text { Wall } \\
\text { (in.) } \\
\end{array}$ & $\begin{array}{c}\text { Direction } \\
\mathrm{A}\end{array}$ & & & $\begin{array}{c}\text { Direction } \\
\mathrm{B} \\
\end{array}$ \\
\hline A & 0.50 & $+3 \mathrm{~dB}$ & & & $+6 \mathrm{~dB}$ \\
\hline B & 0.50 & $+5 \mathrm{~dB}$ & Direction & Direction & $+5 \mathrm{~dB}$ \\
\hline C & 0.25 & $+6 \mathrm{~dB}$ & A & B & $+10 \mathrm{~dB}$ \\
\hline D & 0.50 & $+3 \mathrm{~dB}$ & & & $+5 \mathrm{~dB}$ \\
\hline $\mathrm{E}$ & 0.25 & $+14 \mathrm{~dB}$ & & Clad & $+5 \mathrm{~dB}$ \\
\hline $\mathrm{F}$ & 0.15 & $+4 \mathrm{~dB}$ & & & $+8 \mathrm{~dB}$ \\
\hline G & 0.50 & $+1 \mathrm{~dB}$ & & & $+2 \mathrm{~dB}$ \\
\hline $\mathrm{H}$ & 0.75 & $+6 \mathrm{~dB}$ & Flaw & & $+12 \mathrm{~dB}$ \\
\hline I & 0.75 & $+9 \mathrm{~dB}$ & & & $+1 \mathrm{~dB}$ \\
\hline
\end{tabular}

(a)Access to these two samples was made possible through J.R. Quinn, Electric Power Research Institute (EPRI), Palo Alto, Cal ifornia.

(b) Sensitivity Standard: $1 / 8$ in. dia., flat-bottom reference reflector. 
Figures 2 through 6 show the relative signal amplitudes for: a $1 / 8$ in. dia., flat-bottom hole (FBH) at the interface, an ASME-type through-clad notch, thermal fatigue under-clad cracks, under-clad notches, the base 1 ine noise, and indications from within the clad. The base line is the level which would yield a nearly continuous recording. Occasional clad indications arise from the clad itself and are particularly prevalent when signal propagation is perpendicular to ungound clad. These clad signals have been measured and will be addressed later.

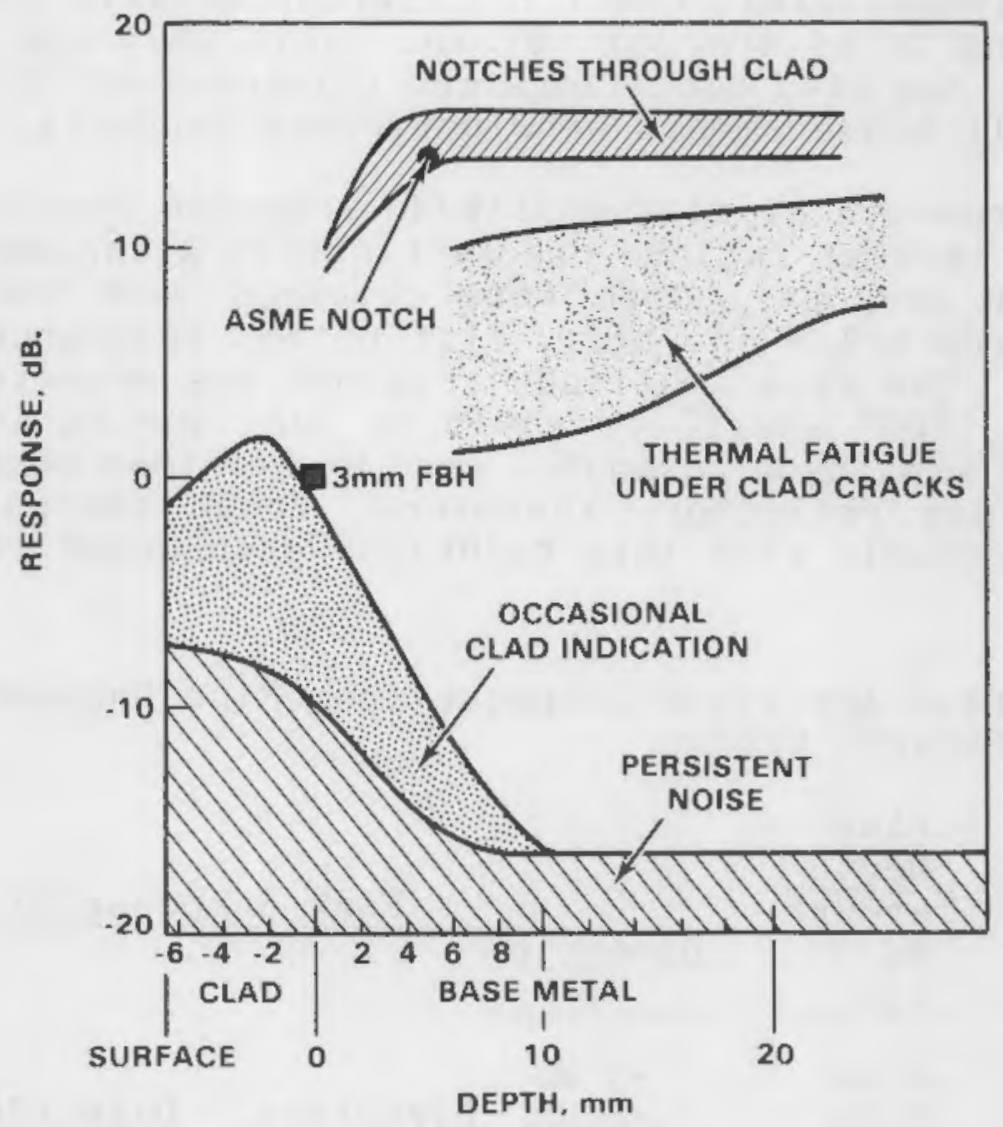

FIGURE 2. Flaw Response from Pressurizer Dropout.

The samples in Figures 2 through 4 each exhibit similar responses and good signal-to-noise ratios. Calibration gain was within $+2 \mathrm{~dB}$ for each of the three samples. The signal-to-noise ratio for the ground single-wire clad of Figure 5 is slightly less, but satisfactory. An additional gain of $6 \mathrm{~dB}$ was required for calibration of the sample in Figure 5 over that used for the samples in Figures 2 through 4 . An additional gain of 14 dB was required for calibration of the unground single-wire clad of Figure 6. 


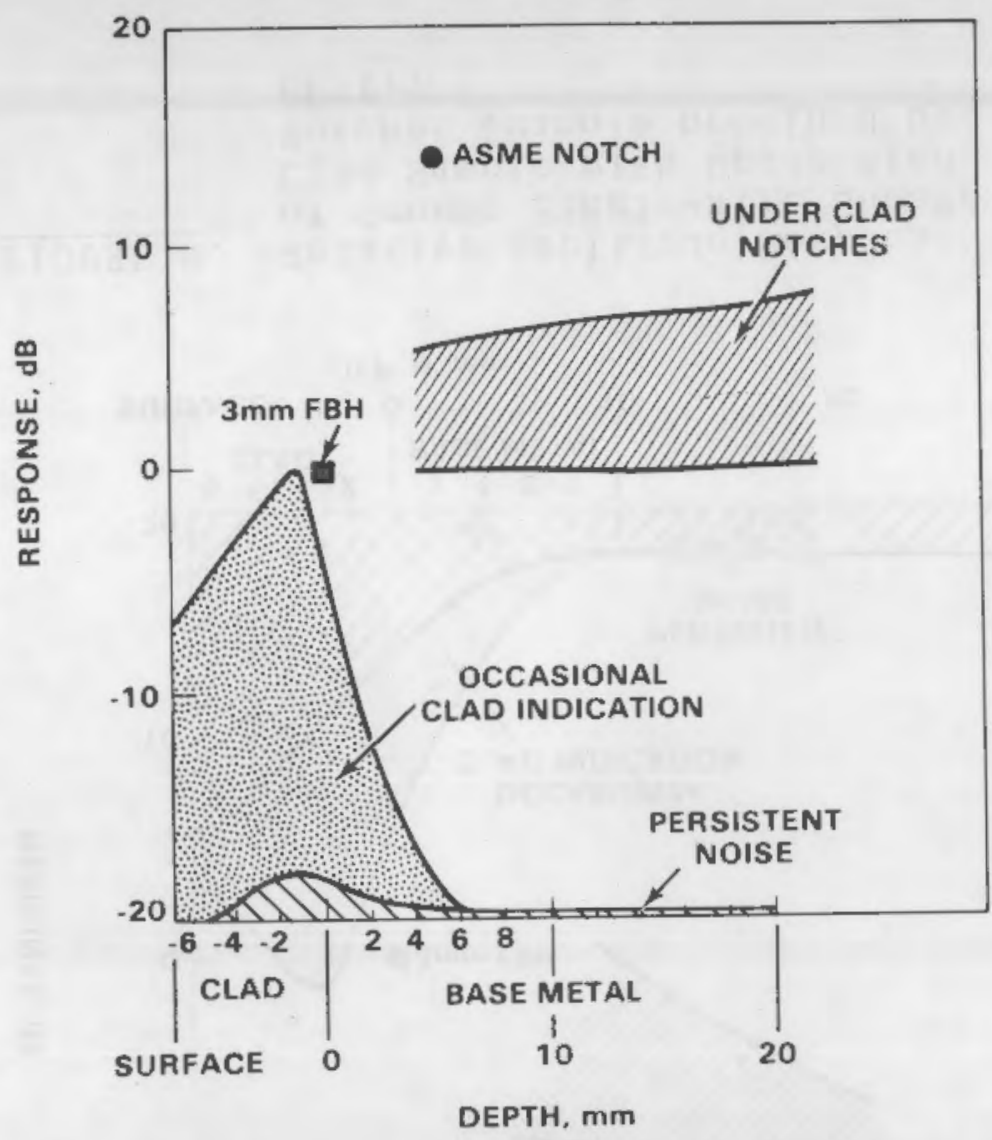

FIGURE 3. Relative Amplitude Response of Ground Strip Clad Sample with Under-clad Notches (sample provided by EPRI).

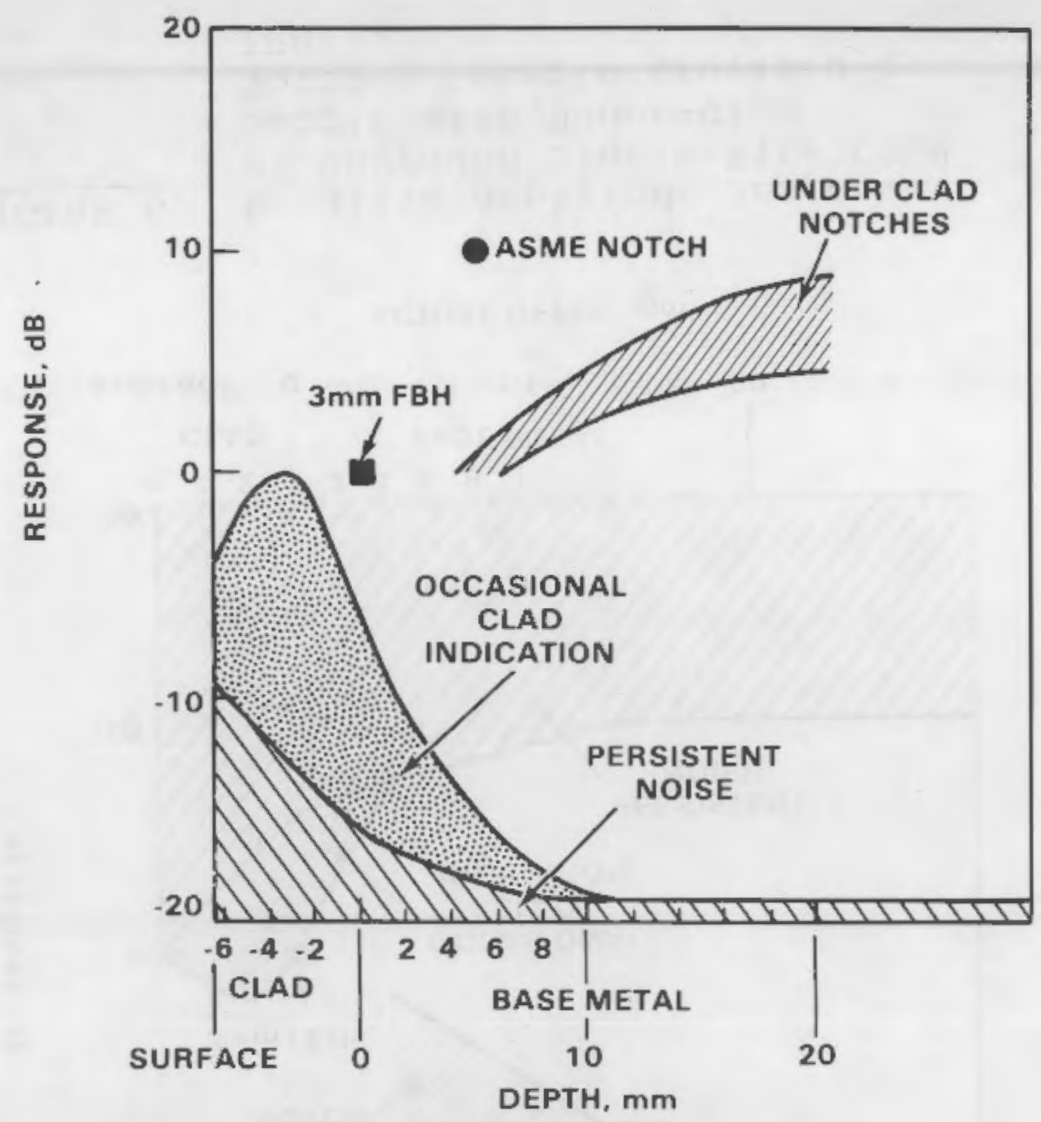

FIGURE 4. Relative Amplitude Response of Unground Strip Clad Sample with Under-clad Notches (sample provided by EPR I). 


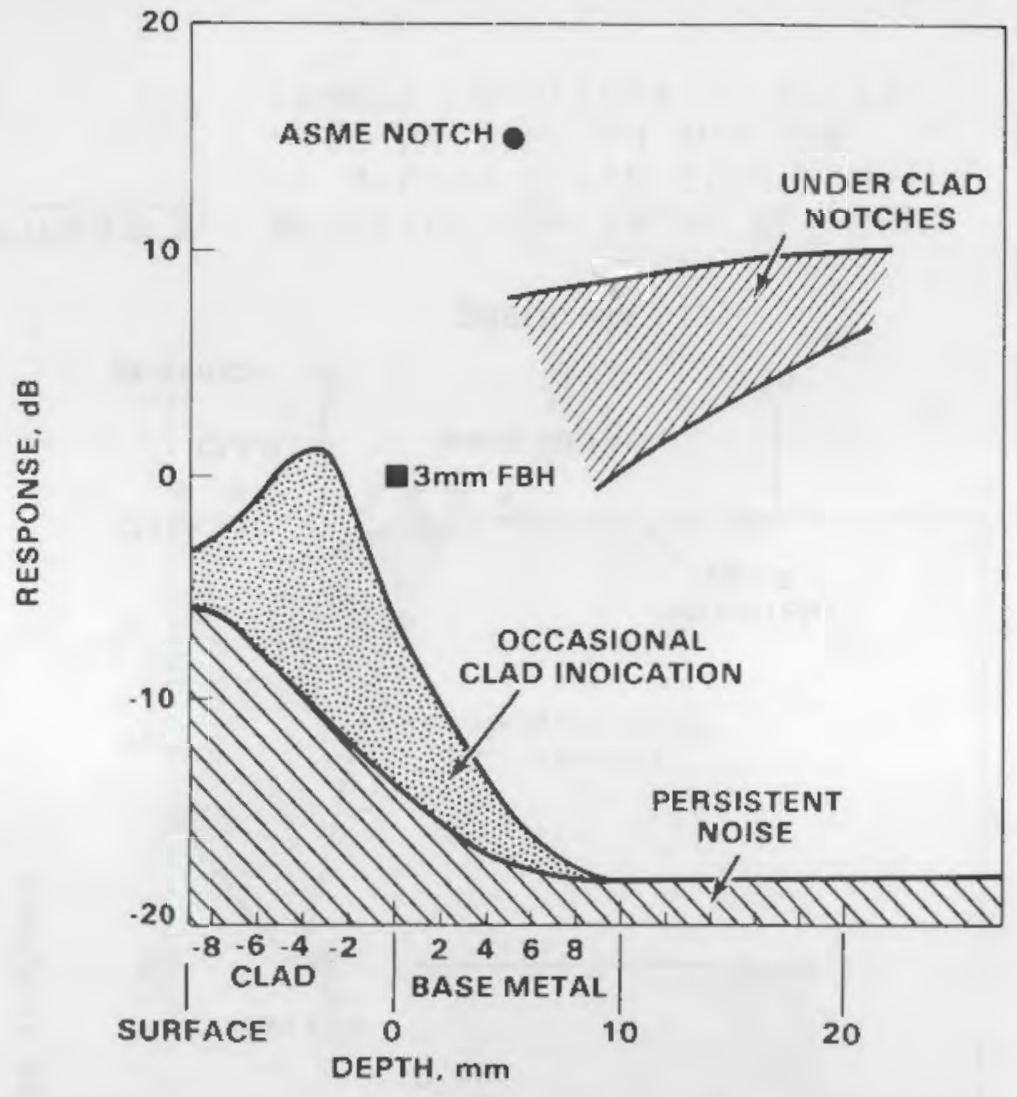

FIGURE 5. Relative Amplitude Response of Ground Single-Wire Subarc Clad Sample with Under-clad Notches (sample provided by EPR I ).

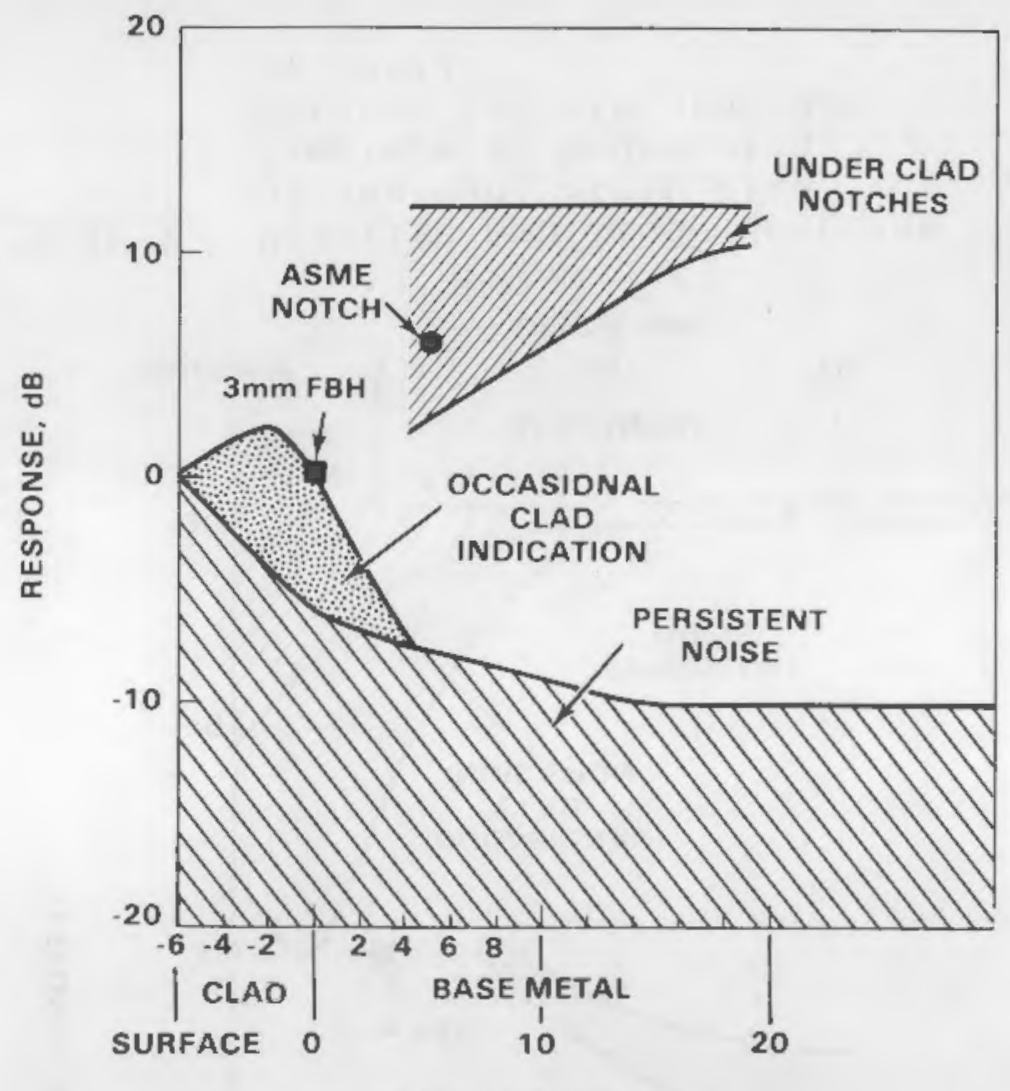

ACTUAL DEPTH, mm

FIGURE 6. Relative Amplitude Response of Unground Single-Wire Clad Sample with Under-clad Notches (sample provided by EPRI ). 
The flaw detectability measurements just described show a marked dependance on surface condition (i.e., "as welded" versus ground). To provide an estimate of inspectability under noisy clad conditions, noise level measurements were made on manually clad test blocks.

The test blocks used for the noise level measurements are shown in Figure 7 . Both blocks were clad using stainless steel, single-wire, manual metal arc welding and contain a $1 / 8$ in. dia., flat-bottom hole. The block shown in Figure 7 a was "as welded" and the block in Figure $7 \mathrm{~b}$ was 1 ightly hand ground.

Noise level measurements were made on both samples by adjusting the response from a $1 / 8 \mathrm{in}$. dia., flat-bottom-hole to $80 \%$ of full screen height. A time exposure photograph was taken of background noise generated while scanning perpendicular to the clad in a defect-free area of the clad specimens.

This technique, while perhaps crude, provides a method for recording peak background noise. A measure of peak background noise is important because an operator must be able to differentiate signals of interest from inherent background noise.

Figure 8 illustrates the results of ultrasound energy backscattered from two conditions of surface finish. Figure 8a shows large amounts of backscattered ultrasound energy resulting from a rough "as clad" surface; this condition makes signal interpretation very difficult for examination personnel. Light hand grinding can reduce backscattered energy 10 to $12 \mathrm{~dB}$ as shown in Figure $8 \mathrm{~b}$.

A measurement of surface roughness was also performed to quantify the "improvement" of surface condition with grinding. These measurements were taken using a linear variable differential transformer (LVDT) that was attached to a stylus and moved across the surface of the test block both parallel and perpendicular to the clad. Figures 9 and 10 show the results of these measurements. The change in surface roughness measurements from $0.012 \mathrm{in}$. RMS for the as-welded surface to 0.006 in. RMS for the hand-ground surface reduced backscattered energy 10 to $12 \mathrm{~dB}$.

To understand why surface roughness has such a dramatic effect on background noise, a simple computer program was developed that used Snell's Law to trace the path of the ultrasound. The program cannot be used to model the ultrasound beam, but is very useful for showing trends in the ultrasonic beam scatter. Since the program can trace ultrasonic rays through an arbitrary surface condition, surface profile mea- 


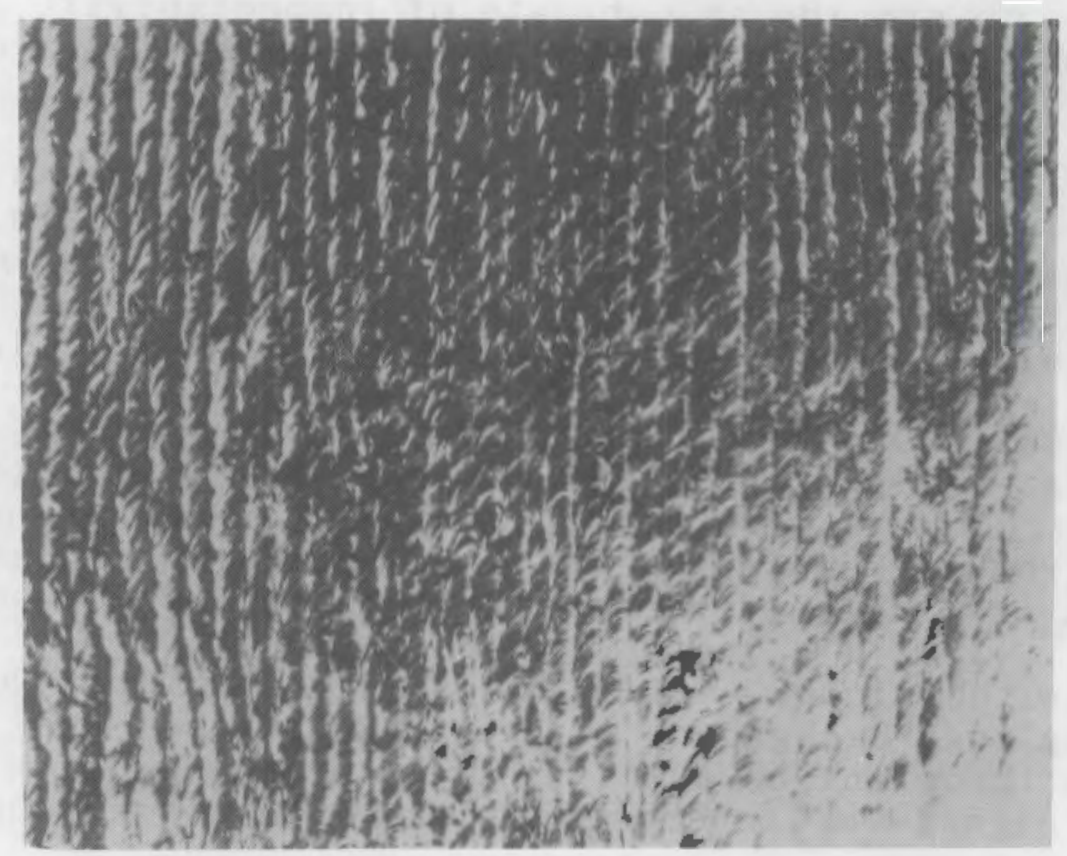

a) As-welded Condition

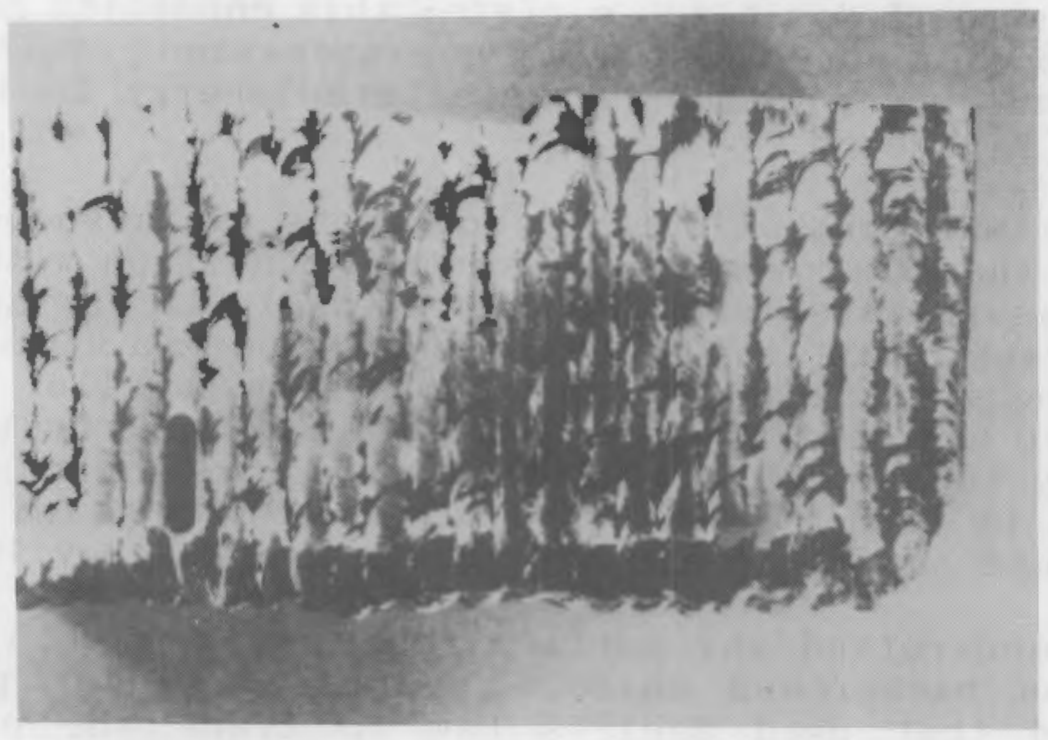

b) Hand-Ground Condition

FIGURE 7. Test Blocks for Background Noise. 

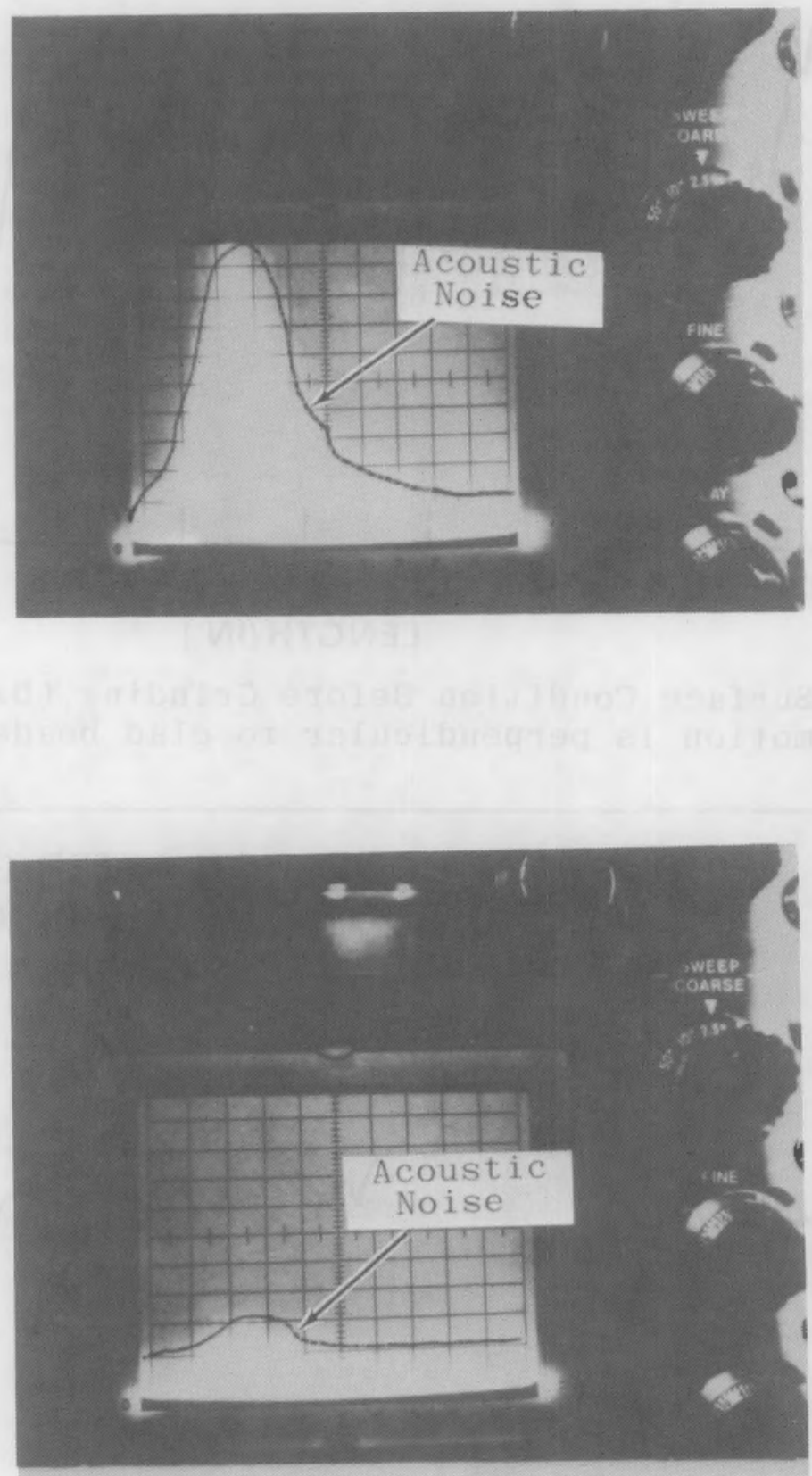

Background Noise for Hand-Ground Condition

FIGURE 8. Background Noise Measurements. 


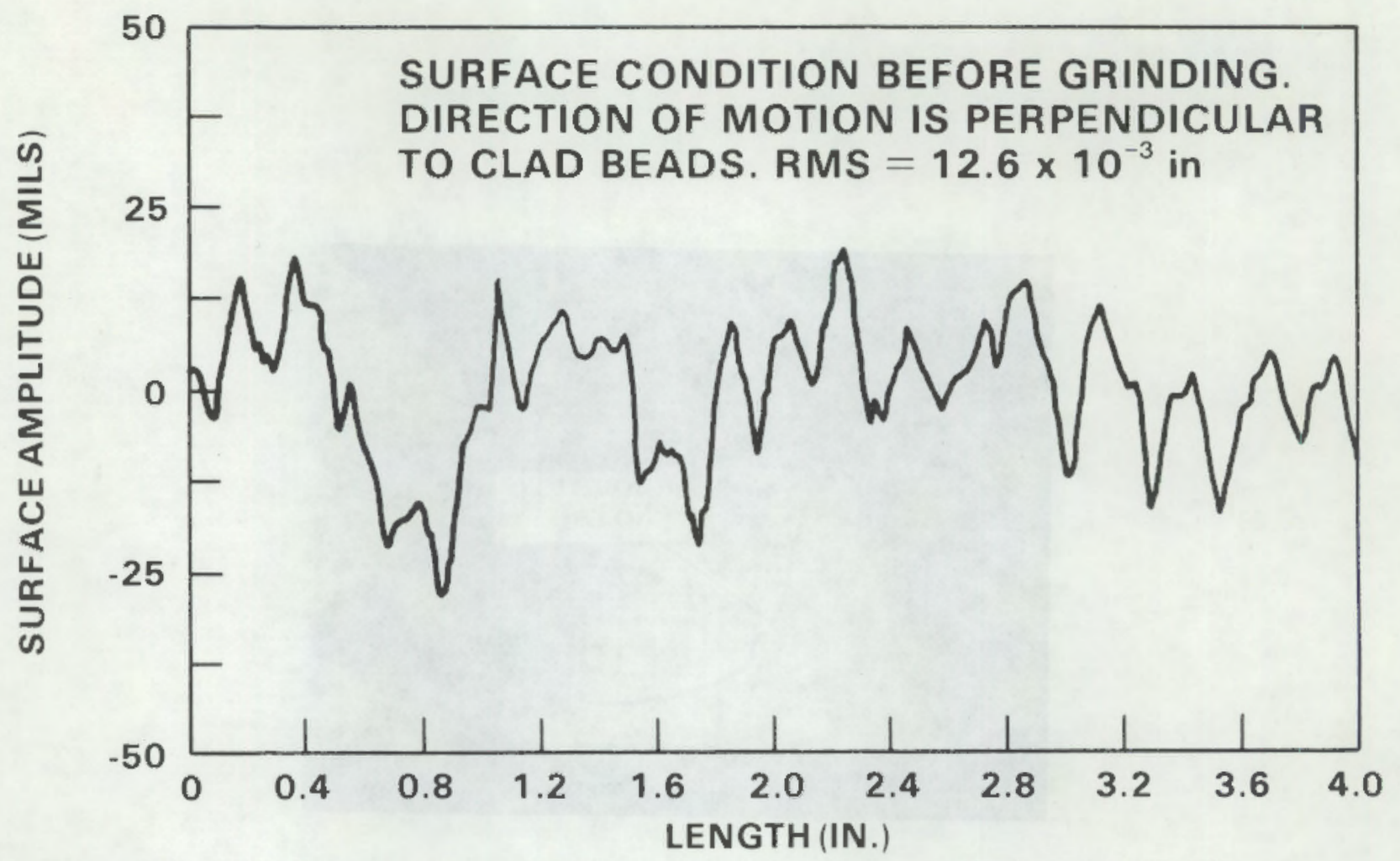

FIGURE 9. Surface Condition Before Grinding (Direction of motion is perpendicular to clad beads).

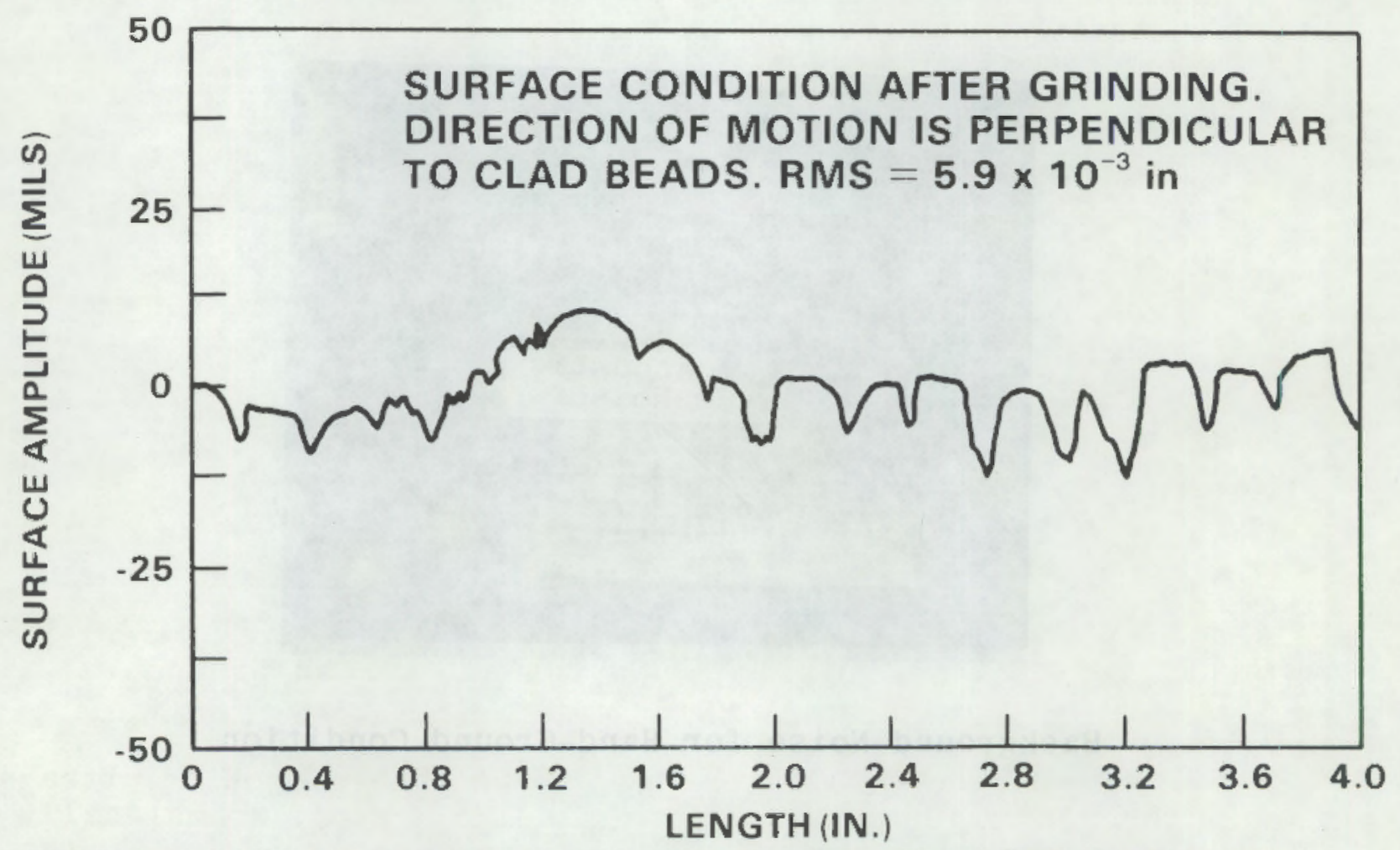

FIGURE 10. Surface Condition After Grinding (Direction of motion is perpendicular to clad beads). 
surements of the "as-welded" condition and hand-ground surface were plotted to show the relative scatter of sound for each condition.

Figure 11 shows the scatter of ultrasound when penetrating an as-welded clad surface. Figure 12 shows the scatter of ultrasound when penetrating hand-ground surface.

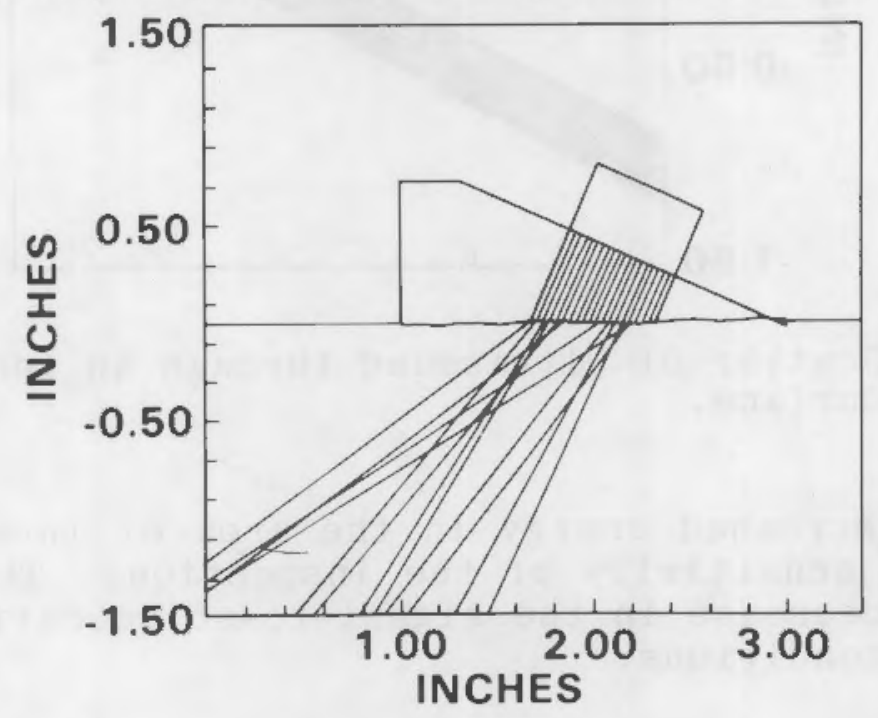

FIGURE 11. Scatter of Ultrasound through an Unground Clad Surface.

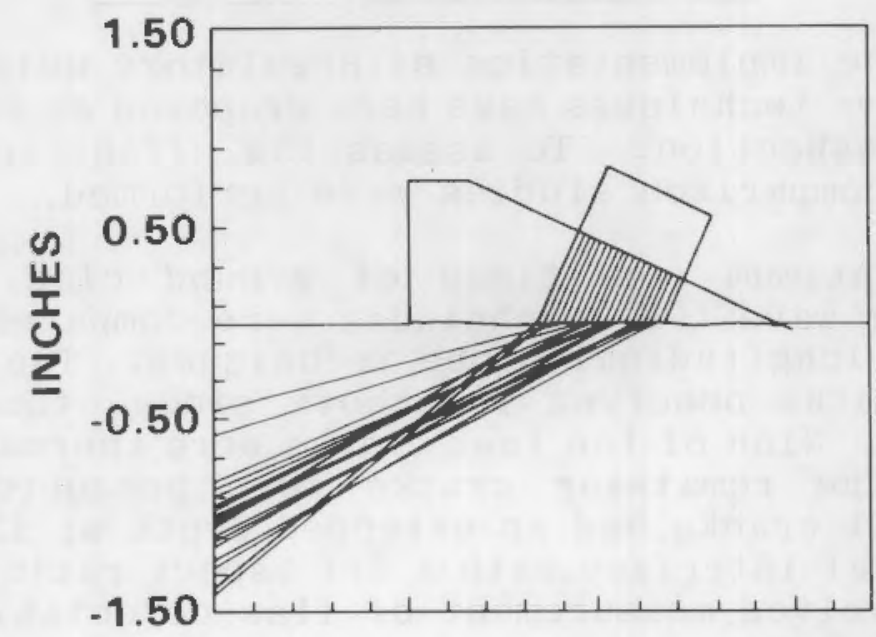

FIGURE 12. Scatter of Ultrasound through a Hand Ground clad Surface.

For comparison, Figure 13 shows the penetration of ultrasound through an ideally smooth surface. The plots dramatically illustrate that the welded surface increases scatter of the ultrasound considerably. This scattering of the ultrasound 


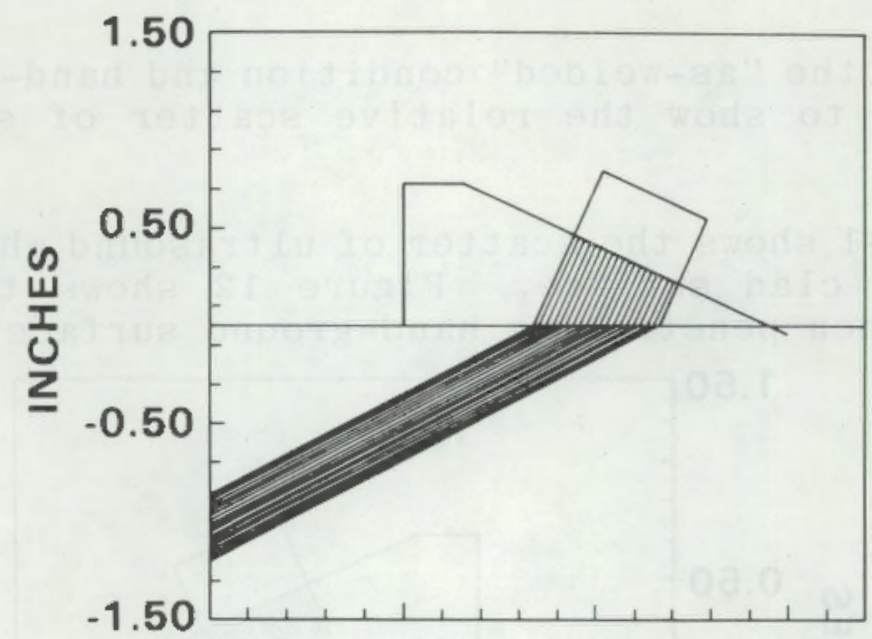

FIGURE 13. Scatter of Ultrasound through an Ideal (Smooth) Surface.

results in decreased energy in the area of interest, thereby reducing the sensitivity of the inspection. This would also explain the decrease in the signal-to-noise ratio for the aswelded clad conditions.

\section{COMPARISON OF PULSE ECHO SHEAR WAVE AND DUAL ELEMENT TECHNIQUES}

Since the implementation of Regulatory Guide 1.150 , several shear wave techniques have been proposed or used for underclad crack inspection. To assess the effectiveness of these techniques, comparison studies were performed.

Under optimum conditions of ground $\mathrm{clad}, 60^{\circ}$ and $70^{\circ}$ contact shear wave (PE) techniques were compared with contact dual element longitudinal probe techniques. The test involved use of 12 cracks observed from both sides, thus allowing 24 observations. Nine of the test cracks were thermal fatigue type cracks and the remaining cracks were produced by hydrogen cracking. All cracks had an extended depth of $12 \mathrm{~mm}$ below the clad/base metal interface with a $3: 1$ aspect ratio. The comparison test involved measurement of flaw detectability and flaw amplitude response.

All techniques were calibrated using a $1 / 16$ in. diameter side-drilled hole (SDH). The results of the comparison test are shown in Table 2 below. 
TABLE 2. Crack Detection Performance

\begin{tabular}{|c|c|c|c|c|}
\hline $70^{\circ}$ & $60^{\circ}$ & $45^{\circ}$ & $60^{\circ}$ & $70^{\circ}$ \\
\hline Shear & Shear & Long. & Long. & Long. \\
\hline Single & Single & Dual 1 & Dua 1 & Dual \\
\hline 7 & 6 & 0 & 0 & 0 \\
\hline 17 & 18 & 24 & 24 & 24 \\
\hline 5.8 & -8.5 & 7.7 & 1.2 & +2.7 \\
\hline
\end{tabular}

Both shear wave pulse echo techniques not only failed to detect a quarter of the flaws, but provided very poor flaw amplitude response and signal-to-noise ratio. The dual element longitudinal wave techniques performed much better. The $45^{\circ}$ dual element longitudinal techniques provided poor amplitude response; however, the improved signal-to-noise ratio allowed all flaws to be detected. The $70^{\circ}$ dual element longitudinal technique proved to be the best performer. Using this technique, all flaws produced responses above the 1/16 in. SDH reference level.

\section{UNDER-CLAD CRACK CHARACTERIZATION}

Characterization of a crack after detection provides estimates of crack size (both length and depth) so appropriate engineering decisions can be made for crack disposition.

Crack sizing via the crack tip diffraction technique (see Figure 14) was investigated for underclad cracks. Ultrasound energy is reflected from both the face of the crack and diffracted from both the top and bottom tips. This sizing technique involves detecting ultrasound energy diffracted from the bottom of the crack tip. The 12 cracks used in the comparison test previously described were sized using crack tip diffraction with both $45^{\circ}$ and $60^{\circ}$ dual element probes. Crack depths $\left(C_{P}\right)$ were calculated from sound path measurements using the formula

$$
C_{P}=\cos (\theta) \times M_{p} \cdot
$$

where $\theta$ is the inspection angle and $M_{p}$ is the sound metal path. 


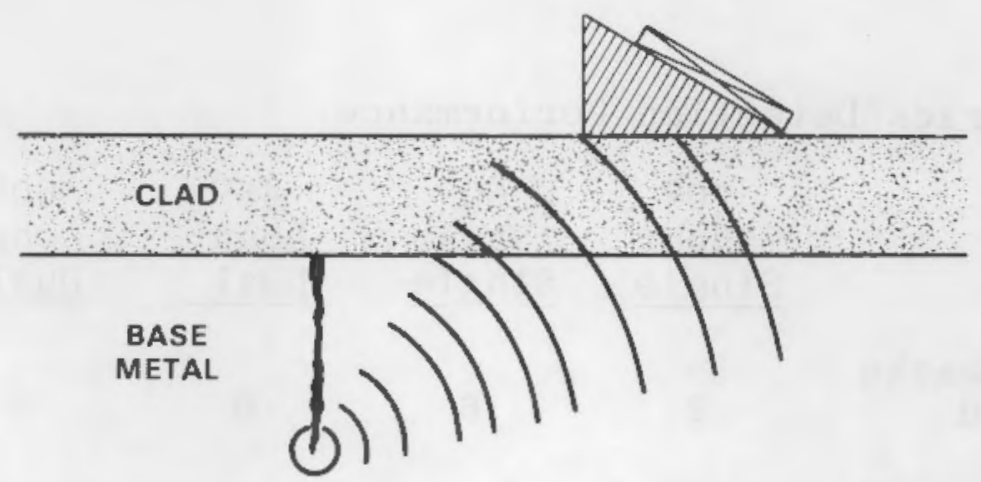

FIGURE 14. Crack Tip Diffraction Technique for Sizing Underclad Cracks.

In addition, under-clad nocthes of known depth were also sized. The results of the crack sizing experiments are shown in Table 3. The results of the notch sizing experiments.

TABLE 3. Crack Sizing Data for Matrix I Flaws.

\section{$\underline{45^{\circ}}$ Sizing}

Crack Description

Type
Hydrogen cracki
Thermal fatigue
through clad

Thermal fatigue

Hydrogen cracking

Thermal fatigue

through clad

Thermal fatigue

\section{Orientation}

1

1

1

1

$60^{\circ}$ Sizing
Depth Ave. (inches)

.673

.675

.768

.680

.763

.765
Sample Std Dev. $S$

.102

.035

.181

.073

.060

.051

$\begin{array}{lll}11 & .713 & .180 \\ 1 & .723 & .229 \\ 11 & .903 & .167 \\ 1 & .690 & .048 \\ 11 & & \\ 1 & 1.033 & .311 \\ & 1.078 & .139\end{array}$


The $60^{\circ}$ dual element probe provided very good correlation to theory for both cracks and notches when compared with actual defect size (Figure 15). The $45^{\circ}$ probe shows a good correlation between sound beam path measurements and defect size. However, the experimental results indicate the cladding is affecting the propagation path of the $45^{\circ}$ longitudinal wave for the notches resulting in consistently undersizing them as shown in Figure 16.

Wooldridge (1982) has shown that the grain structure of stainless steel cladding tends to act as a waveguide for $45^{\circ}$ shear. Since clad grains tend to be oriented normal to the ferritic base metal, this means that $45^{\circ}$ shear ultrasound propagates in the manner shown in Figure 17. If the propagation model that Wooldridge used for $45^{\circ}$ shear is applied to the $45^{\circ}$ longitudinal wave data, the mathematical model in Figure 17 can be applied. The results of this assumption are shown in Figure 18, which shows an excellent correlation.

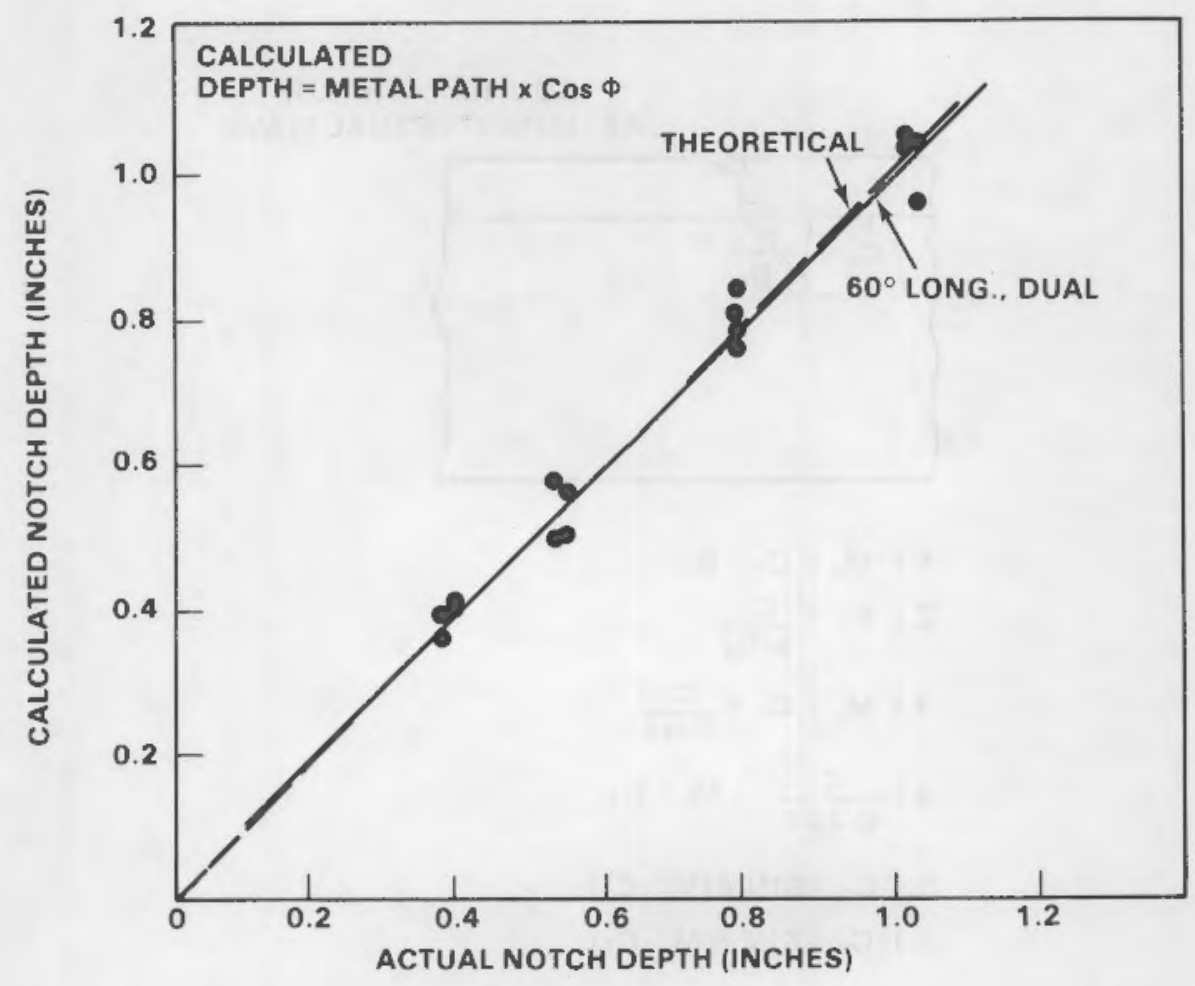

FIGURE 15. Experimental Sizing Data for $60^{\circ}$ Longitudinal Dual. 


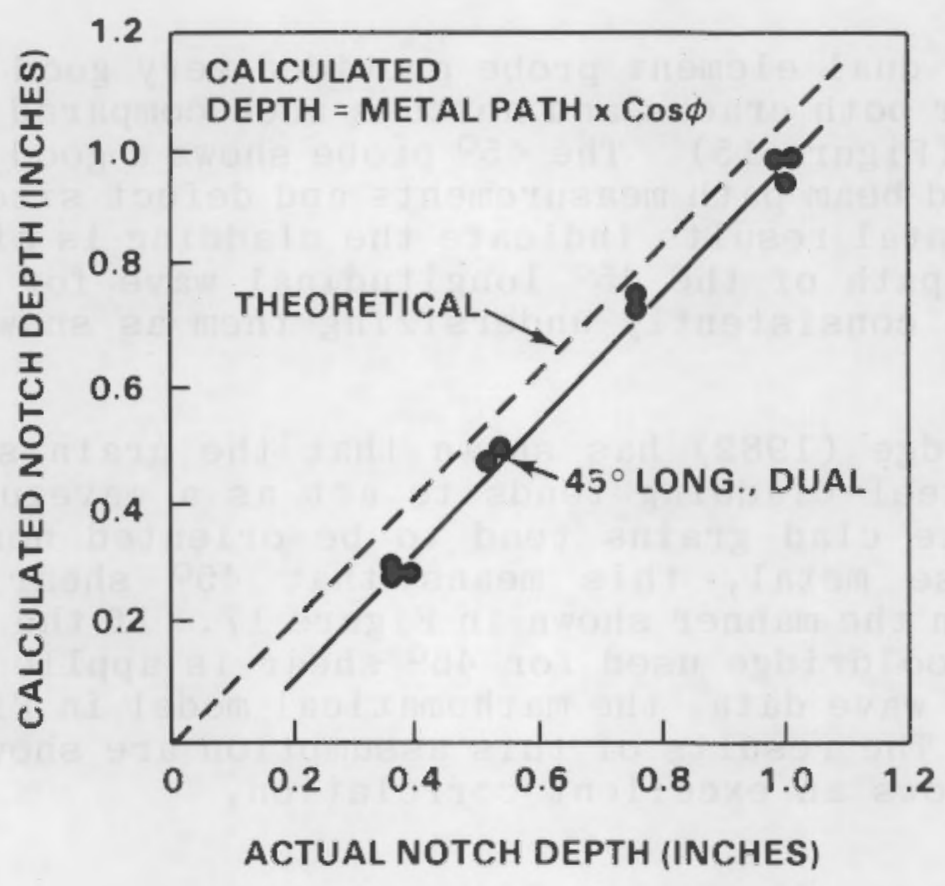

FIGURE 16. Experimental Sizing Data for $45^{\circ}$ Longitudinal Dual.

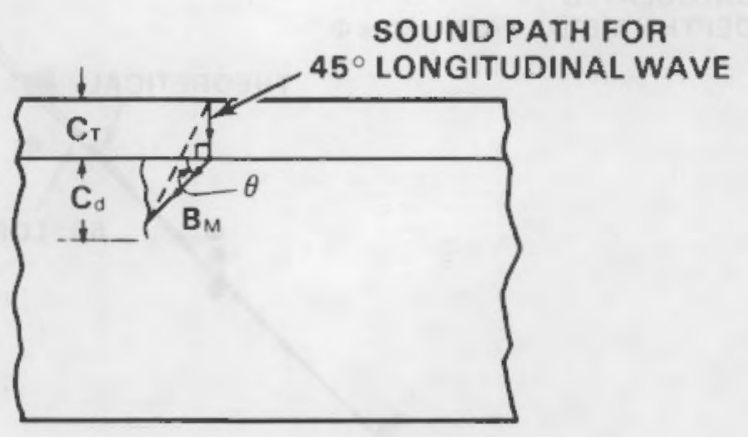
1.) $M_{P}=C_{T}+B_{M}$
2.) $B_{M}=\frac{C_{d}}{\sin \theta}$
3.) $\mathbf{M}_{\mathrm{p}}=\mathbf{C}_{\mathrm{T}}+\frac{\mathbf{C}_{\mathrm{d}}}{\sin \theta}$
4.) $\frac{C_{d}}{0.707}=M_{p}-C_{T}$
5.) $\mathrm{C}_{\mathrm{d}}=\operatorname{SIN} \theta\left(\mathrm{M}_{\mathrm{p}}-\mathrm{C}_{\mathrm{T}}\right)$
6.) $C_{d}=\operatorname{SIN} \theta\left(M_{p}-C_{T}\right)$

FIGURE 17. Sound Path through Clad Surface for Shear Waves. 


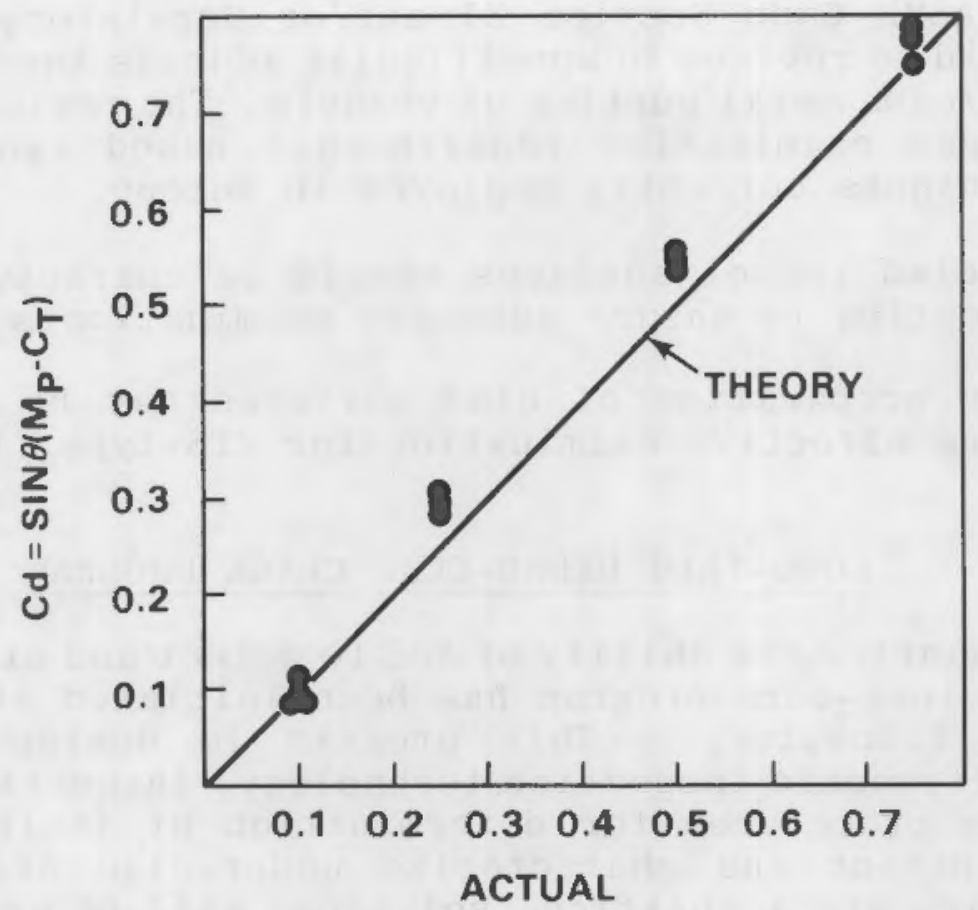

FIGURE 18. Correlation of Proposed Sound Path to Experimental Data (each axis has units in inches).

The experimentation performed is not intended to show that the modelling done for shear waves applies to longitudinal waves. Rather, it shows that stainless steel clad does affect the propagation path of longitudinal ultrasound in steel. Further work is planned to develop a model based on elastic constraints and grain orientation to explain our experimental data.

\section{CONCLUSIONS}

Based upon the work performed to date on the vessel application task, the following conclusions can be drawn:

- Few U.S. reactor vessels have been effectively examined for PTS-type flaws, based on comparison testing between U.S. standard practice and European techniques.

- For future inservice inspection of U.S. reactor pressure vessels, a $1 / 16$ inch diameter side-drilled hole or $1 / 8 \mathrm{inch}$ diameter flat bottom calibration reflector should be added to existing vessel calibration blocks for examination of the $\mathrm{clad} /$ base metal region. 
- The ASME Code Section XI and/or Regulatory Guide 1.150 should be revised to specifically address inspection of the clad/base metal portion of vessels. The revision(s) should include examination requirements based upon inspection techniques currently employed in Europe.

- All clad vessel surfaces should be characterized before inspection to ensure adequate examination sensitivity.

- Minor preparation of clad surfaces may be necessary to ensure effective examination for PTS-type flaws.

\section{LONG-TERM UNDER-CLAD CRACK PROGRAM}

To quantify the ability of NDE to detect and size under-clad cracks, a long-term program has been initiated at the Pacific Northwest Laboratory. This program is designed to assess current ultrasonic inspection technology, inspection teams, and inspection procedures for determination of their adequacy to reliably detect and characterize under-clad cracks. Where inadequacies are identified, solutions will be evaluated. The solutions that resolve inadequacies will be recommended for inclusion into the appropriate pressure vessel inspection Codes.

The first task is to evaluate the under-clad crack fabrication techniques. Phase 1 contains the specimens with which six different cracking methods will be used to create the under-clad cracks. Ultrasonic measurements of Phase 1 will provide a comparison of the different cracking methods. Since no experience exists for under-clad cracks in American vessels, the most ultrasonically conservative cracking method will be used.

Phase 2 will be used to evaluate the effects of different clad types and roughness. This is extremely important so that the test sensitivity for a given inspection can be properly established. The clad roughness will be quantified in terms of a surface profile and backscattered noise. Inspection variables such as transducer frequency, size, and angle will be evaluated for the effects of clad conditions. 


\section{REFERENCES}

Becker, F.L. 1982. "Near Surface Detection in Nuclear Pressure Vessels." In Proc. 5th Int. Conf. on NDE. in the Nuclear Industry. Conference held at San Diego, California, May 1982.

DeRaad, J.A., G. Engl, and H. Bergh. 1981. "Inside Ultrasonic Inspection of Innernozzle Radius Corners of Nuclear Pressure Vessels - Contact and Immersion." In Proc. 4th Int. Conf. on NDE in the Nuclear Industry. Conference held at Lindau, West Germany, May 1981 .

Gamble, R.M. and J. Strosnider, Jr. June 1981. An Assessment of the Failure Rate for the Beltline Region of PWR Pressure Vessels During Normal Operation and Certain Transient Conditions. NUREG-0778, U.S. Nuclear Regulatory Commission.

Gruber, G.J. 1982. "Near Surface Detection and Sizing of Unclad Cracks in Nuclear Cracks in Nuclear Reactor Vessels by Ultrasonic Multiple-Beams Technique." In Proc. 5th Int. Conf. on NDE in the Nuclear Industry. Conference held at San Diego, California, May 1982 .

Launay, J.P. et al. 1981. "Nondestructive Evaluation of Underclad Defects." In Proc. 4th Int. Conf. on NDE in the Nuclear Industry. Conference held at Lindau, West Germany, May 1981 .

Wooldridge, A.B., D.J. Allen and D. Denby. June 1982. "Predicting and Minimising the Adverse Effects of Austenitic Cladding on Ultrasonic Inspection of PWR Primary Circuit Components." CEGB Report No. NWR/SSD/82/0072/R. 

NUREG/CR-2878

PNL-4373

R5

\section{DISTRIBUTION}

No. of

Copies

U.S. Nuclear Regulatory

Cormission

Division of Technical Informa-

tion and Document Control

7920 Nor folk Avenue

Bethesda, MD 20014

R.F. Abbey, Jr.

Office of Nuclear Regulatory

Research

Nuclear Regulatory Commission

Washington, DC 20555

S. Fabric

Office of Nuclear Regulatory

Research

Nuclear Regulatory Commission

washington, DC 20555

D. A. Hoatson

Office of Nuclear Regulatory Research

Nuclear Regulatory Commission

Washington, DC 20555

w. v. Johnston

Office of Nuclear Regulatory Research

Nulcear Regulatory Commission

washington, DC 20555

10 J. Muscara

Materials Engineering $\mathrm{Branch}$ Engineering Technology Division Nuclear Regulatory Commission Mail Stop 5650NL

Washington, DC 20555
No. of

Copies

\author{
R. D. Schamberger \\ Office of Nuclear Regulatory \\ Research \\ Nuclear Regulatory Commission \\ Washington, DC 20555 \\ H. H. Scott \\ Office of Nuclear Regulatory \\ Research \\ Nuclear Regulatory Commission \\ washington, DC 20555 \\ R. Van Houton \\ Office of Nuclear Regulatory \\ Research \\ Nuclear Regulatory Commission \\ washington, DC 20555 \\ B. D. Liaw \\ Materials Engineering Branch \\ Division of Engineering \\ Nuclear Regulatory Commission \\ Mail stop 318 \\ Washington, DC 20555 \\ Martin R. Hum \\ Materials Engineering Branch \\ Division of Engineering \\ Nuclear Regulatory Commission \\ Mail Stop 318 \\ Washington, DC 20555 \\ Flix B. Litton \\ Materials Engineering Branch \\ Division of Engineering \\ Nuclear Regulatory Commission \\ Mail Stop 318 \\ washington, DC 20555
}


No. of

Copies

Warren S. Hazelton

Materials Engineering Branch

Division of Engineering

Nuclear Regulatory Commission

Mail Stop 318

Washington DC 20555

w. J. Collins

Office of Inspection and Enforcement

Nuclear Regulatory Commission

washington, DC 20555

Bob Herman

Office of Inspection and

Enforcement

Nuclear Regulatory Commission

washington, DC 20555

Glen A. Walton

Region I

Office of Inspection and Enforcement

Nuclear Regulatory Commission

631 Park Avenue

King of Prussia, PA 19406

Alan R. Herdt

Region II

Office of Inspection and

Enforcement

Nuclear Regulatory Commission

Suite 3100

101 Marietta Street NW

Atlanta, GA 30303

Dr. V. Goel

office of standards

Nuclear Regulatory Commission

washington, DC 20555

Lou Frank

Office of Standards

Nuclear Regulatory Commission

Washington, DC 20555
No. of

Copies

R. W. Weeks

Materials Science Division

Argonne National Laboratory

Argonne, IL 60439

F. Shakir

Department of Metallurgy

Association of American Railroads

3140 S. Federal

Chicago, IL 60616

$\mathrm{Mr}$. L. J. Anderson, B2402

Dow Chemical Company

Texas Division

P.O. Drawer K

Freeport, TX 77541

L. Agree

Electric Power Research Institute 3212 Hillview Avenue

P.O. Box 10412

Palo Alto, CA 94304

B. R. Sehgal

Electric Power Research Institute 3212 Hillview Avenue

P.O. Box 10412

Palo Alto, CA 94304

W. L. Pear 1

Nuclear Water \& Waste Technology

P.O. Box 6406

San Jose, CA 95150

M. A. Wolf

Department of Atmospheric Sciences

Oregon State University

Corvallis, OR 97330

D. O. Harris

Science Applications, Inc.

5 Palo Alto Square, Suite 200

Palo Alto, CA 94304

SM-ALC/MMET

Attn: Capt. John Rodgers

McClellan AFB, CA 95652 
No. of

Copies

Mr. Jerry Whittaker

Union Carbide Company

Oak Ridge National Laboratories Y-12

Oak Ridge, TN 37830

Dr. Sotirios, J. Vahaviolos

Western Electric, ERC

P.O. Box 900

Princeton, NJ 08540

Mr. M. C. Jon

Western Electric, ERC

P.O. Box 900

Princeton, NJ 08540

P. Caussin

Vincotte

1640 Rhode-Saint-Genese

BELGIUM

ACE Sinclair

Research Division

Berkeley Nuclear Laboratories

Berkeley

Gloucestershire, CL 139 PB

U.K.

Don Birchon

Admiralty Materials Laboratory

Holton Health Poole

Dorser , ENGLAND

020-122-2711

I. P, Bell

Risley Nuclear Labs

UKAEA

Risley Warrington

Cheshire

U.K.

M. J. Whittle

NDT Application Centre

C.E.G.B. Scientific Services

Timpson Road

Manchester M23 9LL

U.K.
No. of

Copies

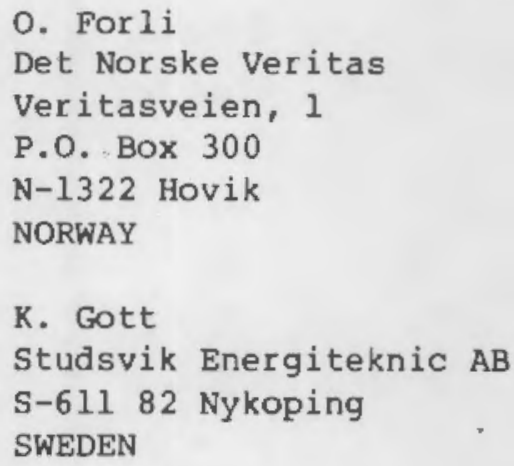

O. For li

Det Norske Veritas

Veritasveien, 1

P.O. Box 300

N-1322 Hovik

NORWAY

K. Gott

Studsvik Energiteknic $A B$

S-611 82 Nykoping

SWEDEN

P. Holler

Institut fur Zerstrarangs Frere

Prufverfahren

Univ. Geb. 37

D-6600 Saarbrucken

WEST GERMANY

X. Edelman

Sulzer Brothers Ltd

Dept. 1513, NDT

CH-8401 winterthur

SWITZERLAND

\section{ONSITE}

50 Pacific Nor thwest Laboratory

M. C. Bampton

S. H. Bush

L. Char lot

R. A. Clark

S. L. Crawford

R. L. Dillon

S. R. Doctor (27)

A. J. Haver field

P. G. Heasler

P. H. Hutton

L. T. Pedersen

S. G. Pitman

G. J. Posakony

G. P. Selby

F. A. Simonen

A. M. Sutey

T. T. Taylor

Technical Information (5)

Publishing Coordination SH (2) 

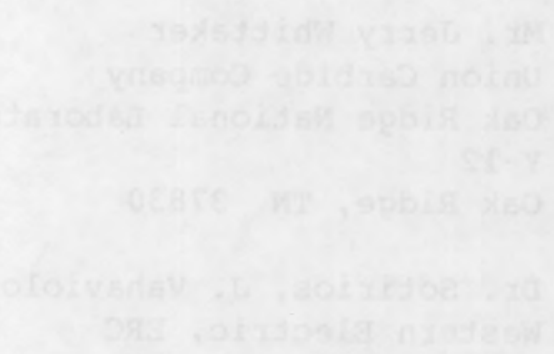

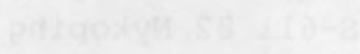

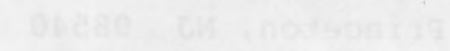

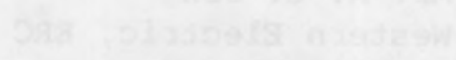

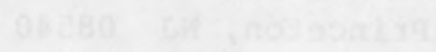

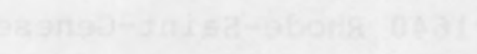

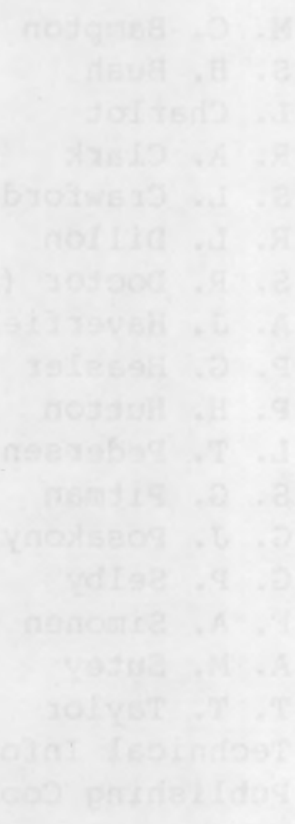

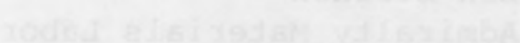

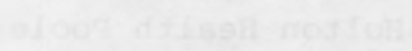

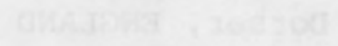

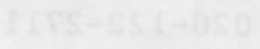

an

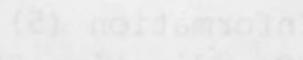




\begin{tabular}{|c|c|c|c|c|c|c|c|c|}
\hline \multirow{3}{*}{\multicolumn{5}{|c|}{ 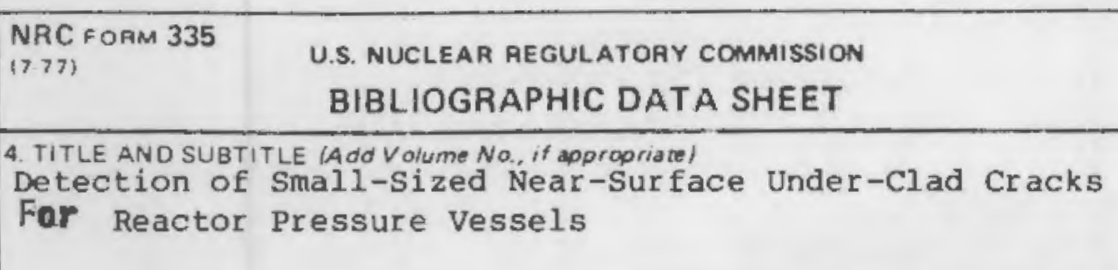 }} & & & & \\
\hline & & \multicolumn{4}{|c|}{ 2. (Leave b/ank) } & & & \\
\hline & & \multicolumn{4}{|c|}{ 3. RECIPIENT'S ACCESSION NO. } & & & \\
\hline \multirow{2}{*}{\multicolumn{5}{|c|}{$\begin{array}{l}\text { 7. AUTHOR(S) } \\
\text { S.L. Crawford, S.R. Doctor, T.T. Taylor }\end{array}$}} & & & & \\
\hline & & & & & & & & \\
\hline \multirow{4}{*}{\multicolumn{5}{|c|}{$\begin{array}{l}\text { 9. PERFORMING ORGAINIZATION NAME AND MAILING ADDRESS (/nclude Zip Code) } \\
\text { Pacific Northwest Laboratory } \\
\text { Richland, WA } 99352\end{array}$}} & & & & \\
\hline & & & & & & & & \\
\hline & & & & & & & & \\
\hline & & \multicolumn{4}{|r|}{ 8. (Leave blank) } & & & \\
\hline \multirow{2}{*}{\multicolumn{5}{|c|}{$\begin{array}{l}\text { 12. SPONSORING ORGANIZATION NAME AND MAILING ADDRESS (Include ZIO Code) } \\
\text { U.S. Nuclear Regulatory Commission } \\
\text { Division of Engineering Technology } \\
\text { Office of Nuclear Regulatory Research } \\
\text { Washington, D.C. } 20555\end{array}$}} & & & & \\
\hline & & \multicolumn{4}{|c|}{$\begin{array}{l}\text { 11. CONTRACT NO. } \\
\text { FIN B2289 }\end{array}$} & & & \\
\hline \multicolumn{9}{|c|}{\begin{tabular}{l|l} 
13. TYPE OF REPORT & PERIOO COV \\
Topical Report &
\end{tabular}} \\
\hline \multicolumn{5}{|c|}{ 15. SUPPLEMENTARY NOTES } & & & & \\
\hline \multirow{2}{*}{\multicolumn{9}{|c|}{ 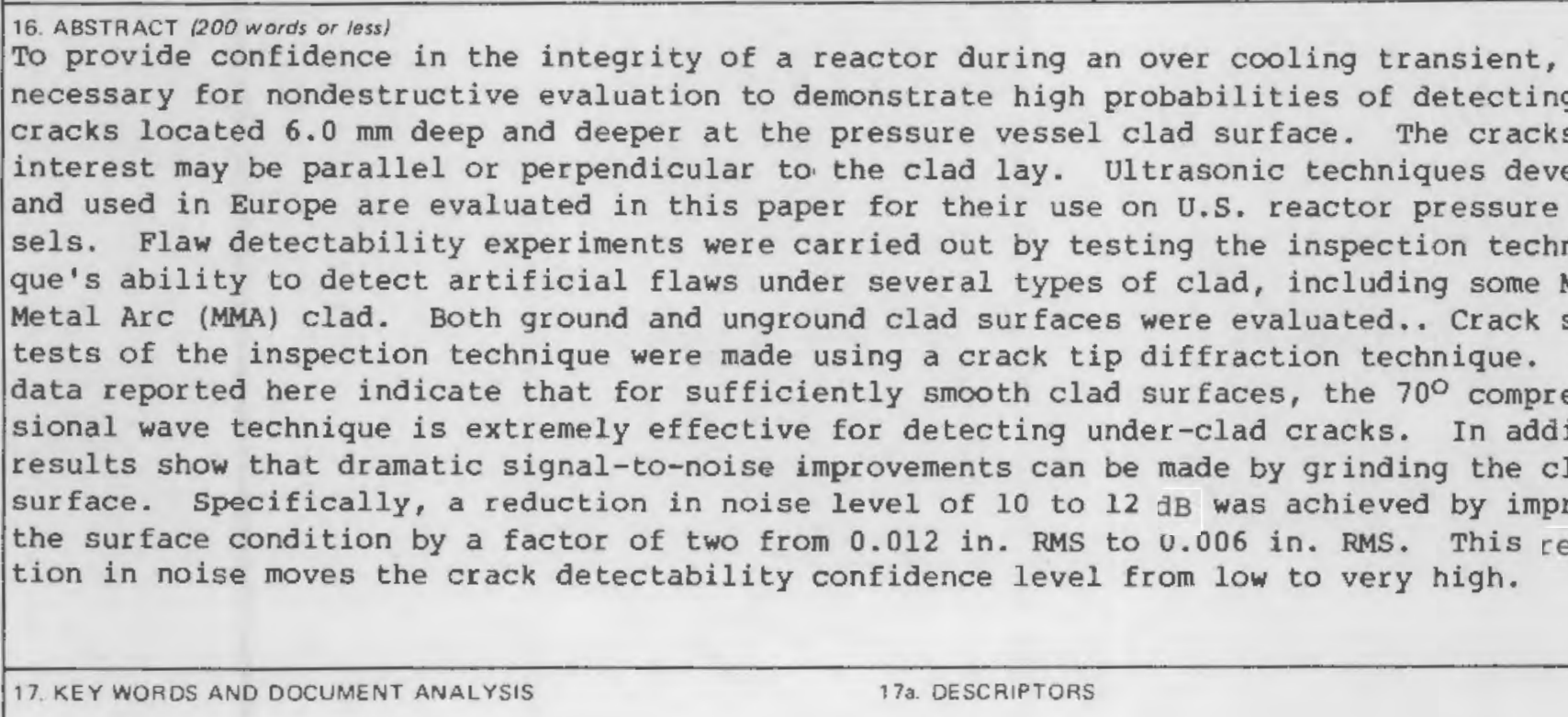 }} \\
\hline & & & & & & & & \\
\hline \multicolumn{9}{|c|}{ 17. KEY WOROS AND DOCUMENT ANALYSIS } \\
\hline \multirow{2}{*}{\multicolumn{5}{|c|}{$\begin{array}{l}\text { 18. AVAILABILITY STATEMENT } \\
\text { Unlimited }\end{array}$}} & & & $\begin{array}{l}\text { CLASS (This report) } \\
\text { fied }\end{array}$ & 21. NO OF PAGES \\
\hline & & & & & & & $\begin{array}{l}\text { CLASS This pagel } \\
\text { Iftied }\end{array}$ & $\begin{array}{l}\text { 22. PRICE } \\
\$\end{array}$ \\
\hline
\end{tabular}


